COVID-19 Sürecinde Demografik, Sosyal, Akademik ve Hastalıkla İlgili Faktörlerin Üniversite Öğrencilerinin Psikolojik İyi Oluşları ile İlişkisi

Aysun Ergül-Topçu, Yeşim Yasak, Temel Kalafat, İlkiz Altınoğlu-Dikmeer

Çankırı Karatekin Üniversitesi Edebiyat Fakültesi Psikoloji Bölümü, Çankırı, Türkiye

Sorumlu Yazar: Temel Kalafat, kalafattemel@hotmail.com

Makale Türü: Araştırma Makalesi

Kaynak Gösterimi: Ergül-Topçu, A., Yasak Y., Kalafat T., ve Altınoğlu-Dikmeer İ. (2021). COVID-19 sürecinde demografik, sosyal, akademik ve hastalıkla ilgili faktörlerin üniversite öğrencilerinin psikolojik iyi oluşları ile ilişkisi. Eğitimde Kuram ve Uygulama, 17(1), 67-83. doi: 10.17244/eku.926595

Etik Not: Araştırma ve yayın etiğine uyulmuştur. Bu çalışma için Çankırı Karatekin Üniversitesi’nden etik kurul onayı (22.04.2020 tarih, 52133317-605-E.9167 sayılı etik kurul kararı) alınmıştır.

The Relationship between Psychological Well-being of University Students and Demographic, Social, Academic and Disease Related Factors During COVID-19 Pandemic

Aysun Ergül-Topçu, Yeşim Yasak, Temel Kalafat, İlkiz Altınoğlu-Dikmeer

Department of Psychology, Faculty of Letters, Çankırı Karatekin University, Çankırı, Turkey

Corresponding Author: Temel Kalafat, kalafattemel@hotmail.com

Article Type: Research Article

To Cite This Article: Ergül-Topçu, A., Yasak Y., Kalafat T., ve Altınoğlu-Dikmeer İ. (2021). COVID-19 sürecinde demografik, sosyal, akademik ve hastalıkla ilgili faktörlerin üniversite öğrencilerinin psikolojik iyi oluşları ile ilişkisi. Eğitimde Kuram ve Uygulama, 17(1), 67-83. doi: 10.17244/eku.926595

Ethical Note: Research and publication ethics were followed. For this study, the ethical approval was obtained from Çankırı Karatekin University Ethics Committee (Date: 22.04.2020, Issue: 52133317-605-E.9167). 



\title{
COVID-19 Sürecinde Demografik, Sosyal, Akademik ve Hastalıkla İlgili Faktörlerin Üniversite Öğrencilerinin Psikolojik İyi Oluşları ile İlişkisi
}

\author{
Aysun Ergül-Topçu, Yeşim Yasak, Temel Kalafat, İlkiz Altınoğlu-Dikmeer \\ Çankırı Karatekin Üniversitesi Edebiyat Fakültesi Psikoloji Bölümü, Çankırı, Türkiye \\ ORCID: https://orcid.org/0000-0002-2657-5983 \\ ORCID: https://orcid.org/0000-0001-5965-244X \\ ORCID: https://orcid.org/0000-0001-5794-9813 \\ ORCID: https://orcid.org/0000-0001-9511-3478
}

\begin{tabular}{|c|c|}
\hline Öz & Makale Bilgisi \\
\hline $\begin{array}{l}\text { Dünyayı etkisi altına alan COVID-19 küresel salgını fiziksel sağlık üzerindeki etkilerinin } \\
\text { yanı sıra psikolojik, sosyolojik ve ekonomik pek çok soruna neden olmuştur. Hastalıkla } \\
\text { ilgili kaygılar, evlerde kapalı kalma, sosyalleşmenin azalması, eğitim süreçlerinin } \\
\text { aksaması ve yaşanan ekonomik zorluklar bireylerin psikolojik iyi oluşlarını olumsuz } \\
\text { yönde etkilemiştir. Bu çalışmada, Türkiye'de COVID-19 sürecinde üniversite } \\
\text { öğrencilerinde, demografik, sosyal, akademik ve COVID-19 hastalığı ile ilgili faktörlerin } \\
\text { psikolojik iyi oluş hali ile ilişkisi incelenmiştir. Çok merkezli uluslararası bir çalışmanın } \\
\text { bir parçası olarak gerçekleştirilen bu çalışmada, gönüllü olan toplam } 378 \text { üniversite } \\
\text { öğrencisinden (yaş ortalaması } 21.59, \mathrm{~S}=2.54 \text { ) veri toplanmıştır. Kullanılan anket formu } \\
\text { COVID-19 Uluslararası Üniversite Öğrencileri İyilik Hali Çalışması yürütücü ekibi } \\
\text { tarafından COVID-19 salgınına özel olarak geliştirilmiştir. } 77 \text { sorudan oluşan anket formu } \\
7 \text { boyut içermektedir (sosyodemografik bilgiler; eğitimle ilgili bilgiler; COVID-19 öncesi } \\
\text { ve sonrası yaşam tarzı; kendisi ve ailesinin genel sağlık ve COVID-19 hastalık bilgileri ve } \\
\text { bununla ilgili yaşanan kaygılar; stres kaynakları, sosyal destek ve psikolojik iyi oluş; } \\
\text { akademik yaşamla ilgili bilgiler ve COVID-19 hastalığ ile ilgili genel bilgi düzeyi). } \\
\text { Araştırma sonuçları, aile yanında geçirilen zamanın artmasının, COVID-19 ile ilgili } \\
\text { endişenin, akademik stresin ve kadın olmanın psikolojik iyi oluş hali için risk faktörleri; } \\
\text { algılanan yüksek sosyoekonomik düzeyin, sosyal desteğin, yüksek akademik } \\
\text { memnuniyetin ve özel ve kişisel konularda konuşacak yakınlıkta birinin varlığının ise } \\
\text { koruyucu faktörler olduğunu göstermiştir. }\end{array}$ & $\begin{array}{l}\text { Makale Geçmişi: } \\
\text { Geliş: } 23 \text { Nisan } 2021 \\
\text { Düzeltme: } 11 \text { Haziran } 2021 \\
\text { Kabul: } 12 \text { Haziran } 2021\end{array}$ \\
\hline
\end{tabular}

Etik Not: Araştırma ve yayın etiğine uyulmuştur. Bu çalışma için Çankırı Karatekin Üniversitesi’nden etik kurul onayı (22.04.2020 tarih, 52133317-605-E.9167 sayılı etik kurul kararı) alınmıştır. 


\section{The Relationship between Psychological Well-being of University Students and Demographic, Social, Academic and Disease Related Factors During COVID-19 Pandemic}

\begin{abstract}
Many people reported a decrease in their psychological well-being after the COVID-19 pandemic. This life-threatening disease caused many health problems, deaths as well as psychological, sociological and economic problems in people's lives. The main purpose of the current study was to examine the relationship between psychological well-being of university students and demographic, social, academic and disease related factors. The current study is conducted as a part of multi-centered COVID-19 International University Students Well-Being Study. The sample of the study consisted of 378 university students (294 females, 81 males and 3 others). The mean age of the sample was 21.59 years (SD = 2.54). The survey used in this study was developed specifically for the COVID-19 outbreak by the executive team of the international study. Results indicated that the time spent with family members, the level of COVID-19 anxiety, the level of academic stress and being female were found to be risk factors for psychological well-being. The protective factors were satisfactory level of socioeconomic resources, social support, level of academic satisfaction and the existence of someone close to talk about private and personal issues.
\end{abstract}

Article Info

Keywords: COVID-19, Psychological well-being, Academic stress, Academic satisfaction, Social support

Article History:

Received: 23 April 2021

Revised: 11 June 2021

Accepted: 12 June 2021

Article Type: Research Article 


\section{Extended Summary}

\section{Introduction}

The entire World was strongly affected by the new Coronavirus Disease (COVID-19) pandemic in 2020. While many people got seriously sick, many died out of the COVID-19 complications. The others suffered from economic setbacks or the psychological factors like anxiety related to the disease, loss and grief related to the loss of their loved ones as well as their social lives. Many people reported a decrease in their psychological well-being after being locked down unexpectedly for an unknown period of time. Different age groups were psychologically affected in various ways. University students who had active lifestyles had to switch to isolated, passive lives because of the lock down related to pandemic. Many had difficulties in the transition from on campus education to online education; adaptation to the new online style was hard, and many students did not have sufficient resources for the online education. The main purpose of the current study was to examine the relationship between psychological well-being of university students and demographic, social, academic and disease related factors.

\section{Method}

The sample of the study consisted of 378 university students ( 294 females, 81 males and 3 other). The mean age of the sample was 21.59 years $(\mathrm{SD}=2.54)$. The survey used in this study was developed specifically for the COVID-19 outbreak by the executive team of the COVID-19 International University Students Well-Being Study (Van de Velde et al., 2020). The survey consists of seven domains (sociodemographic information; academic information; lifestyle before and after COVID-19 outbreak; general health and existence of COVID-19 symptoms in self and the family as well their worries about contamination; general and disease related stressors, social support and mental wellbeing; changes in the academic life; general knowledge about COVID-19) and a total of 77 questions. Prior to data collection, ethical approval was obtained from the University. All students were invited via email to participate in an online survey about their experience with the COVID-19 situation.

\section{Results}

Descriptive results showed that $35.2 \%$ of the participants reported having sufficient financial resources during the pandemic and $37.3 \%$ reported insufficient financial resources. The average score of the participants who stated that they were worried about COVID-19 was $29.56(\mathrm{SD}=15.58$, range $=0-60)$. The average score of the participants who stated that they comply with the COVID-19 measures implemented by the government was $8.84(\mathrm{SD}=1.81$, range $=$ 0 -10). Since the implementation of COVID-19 measures, the rate of contact with their families remained generally the same, while contact with friends has decreased significantly (79.6\%). While $80.4 \%$ of the participants stated that they had someone whom they could talk about all private and personal issues, $19.6 \%$ stated that there was no such person. Social support score average of the participants was $11.4(\mathrm{SD}=3.79$, range $=6-24)$. The rate of students who stated that they communicated with the university counseling service or social unit since the COVID-19 pandemic, was only $13.8 \%$, the rest stated no contact. Majority of the students (47 of 52) who stated that they had communicated with the university counseling service or social unit, reported that they mostly talked about their concerns related to their academic studies.

Correlational analyses revealed that being a female university student is related to having someone to talk about private and personal issues and low level of psychological well-being. Results also showed that as the level of socioeconomic status has increased, the levels of perceived social support, academic satisfaction and psychological well-being has also increased whereas academic stress has decreased. Perceived high social support is related with having someone to talk about private and personal issues, higher academic satisfaction, more communication with academic staff about psychosocial issues and higher psychological well-being. Contact with family members is positively correlated with contact with friends and negatively correlated with psychological well-being. Having someone to talk about private and personal issues is related with higher academic satisfaction and psychological wellbeing. With the increase in academic stress, the level of academic satisfaction and psychological well-being decreased whereas anxiety about COVID-19 increased. Increased level of academic satisfaction is related with the increase in the level of communication with academic staff about academic and psychosocial issues and also psychological wellbeing. Furthermore, as the level of communication with academic staff about academic issues increased, the level of communication with academic staff about psychosocial issues also increased whereas level of contact with counseling services has decreased. Finally, the increase in the level of anxiety about COVID-19 is related with the decrease in psychological well-being. 
The relationship between demographic, social, academic and COVID-19 disease-related factors and psychological well-being of university students was examined by hierarchical regression analyzes. The results showed that psychological wellbeing of the university students during COVID-19 pandemic increased with the increase in socioeconomic status $(\beta=.23, \mathrm{p}<.001)$, availability of someone to share personal and intimate matters $(\beta=.17, \mathrm{p}$ $<.01)$, social support $(\beta=.12, \mathrm{p}<.05)$ and academic satisfaction $(\beta=.12, \mathrm{p}<.01)$. On the other hand, psychological wellbeing decreased as contact with family members $(\beta=-.13, \mathrm{p}<.01)$, academic stress $(\beta=-.27, \mathrm{p}<.001)$, level of communication with the instructor about classes $(\beta=-.11, \mathrm{p}<.05)$ and the level of COVID-19 related anxiety $(\beta=-$ $.19, \mathrm{p}<.001)$ increased. Results also revealed that being a female is related with low level of psychological wellbeing $(\beta=-.14, \mathrm{p}<.01)$.

\section{Discussion}

In this study, the psychological well-being of the university students is examined in relation to demographic, social, academic and disease related factors. Results indicated that the time spent with family members, the level of COVID19 anxiety, the level of academic stress and being female were found to be risk factors for psychological well-being of the university students. The protective factors were satisfactory level of socioeconomic resources, social support, level of academic satisfaction and the existence of someone close to talk about private and personal issues. The findings of the study suggest the necessity of supporting university students financially to reduce the effects of financial inequalities and psychosocially to improve their psychological well-beings. 


\section{Giriş}

Dünya, Corona virus (COVID-19) olarak tanımlanan küresel salgın nedeniyle zor günler geçirmektedir. Dünya Sağl1k Örgütü (WHO, 2021) tarafindan 2020 yılının Mart ayında bu hastalık küresel bir salgın olarak tanımlanmıştır ve halen artan hasta sayısı ve ölümle etkisini devam ettirmektedir. Küresel salgın süreçlerinin fiziksel sağlı açısından etkisinin yanı sıra psikolojik, sosyolojik ve ekonomik birçok etkisi olduğu görülmektedir (McKibbin ve Fernando, 2020; Smith ve ark., 2011). Bu etkilerin yanı sıra bireylerin değişen yaşam koşulları (bunların içinde işyerlerinin kapanması ile ortaya çıkan ekonomik yaşamdaki değişimler, iletişimin azalmasıyla ortaya çıkan sosyal etkileşimdeki azalmalar) ile birlikte bazı psikolojik problemler yaşadıkları da görülmektedir. Yapılan birçok araştırma bireylerin bu süreçte hastalığa yakalanma kaygısı (Jehn ve ark., 2011; Leggat ve ark., 2010), endişe (Garfin ve ark., 2015; Thompson ve ark., 2017), depresyon (Elbay ve ark., 2020), toplumdan kopma ve izolasyon kaygisı (Setbon ve ark., 2011; Wong ve Sam, 2010) gibi duygusal problemler yaşadığını göstermektedir.

\section{Küresel Salgın Süreci ve Psikolojik İyi Oluş Hali}

Genel anlamda bireyin yaşamından memnun olması anlamına gelen psikolojik-öznel iyi oluşu aslında bir anlamda bireyin kendini değerlendirmesi olarak kabul etmek mümkündür. Bu değerlendirmenin hem bilişsel (yaşamına ilişkin genel yargılar) hem de duygusal (yaşantıları memnun edici ya da değil olarak değerlendirme) biçimi bulunmaktadır. Yaşam sürecinde ortaya çıkan olumlu yaşantılar psikolojik-öznel iyi oluşu desteklerken, olumsuz yaşantılar da tam tersi bir etkide bulunmaktadır (Diener ve Diener, 1996). Küresel salgın süreci bu anlamda psikolojik iyi oluş halini etkileyen faktörlerden biridir (Salehinejad ve ark., 2020; Sonderskov ve ark., 2020). Küresel salgın sürecinin getirdiği fiziksel ve duygusal yorgunluk-bıkkınlık hali, hastalığa yakalanma ile ilgili korkular, ekonomik anlamda yaşanan durgunluklar, geleceğe ilişkin belirsizlik gibi konular bireylerin psikolojik iyi oluşlarını etkileyebilmektedir.

Küresel salgın süreci içinde ortaya çıkan en önemli durumlardan biri, bireylerin fiziksel ve duygusal olarak yorgunluk yaşamasıdır. Yorgunluk günlük herhangi bir etkinlikte çabuk yorulma, fiziksel ve duygusal olarak bitkinlik duygusu yaşama, duygusal enerji yoksunluğu çekme, günlük aktiviteleri başlatma ve sürdürmede zorluk çekme, bir şeyleri yapma konusunda istek duymama, net düşünme becerisini kaybetme ve çalışma hayatına odaklanamama gibi zorlukları tanımlamaktadır (Satıcı ve ark., 2020). Morgül ve arkadaşları (2020), yaptıkları çalışmada yorgunluk hissetmeyen bireylerin, hisseden bireylere göre küresel salgının biteceğine ve devletin kontrol sağlayacağına daha fazla inandığını, maske, eldiven takma, elleri yıkama, sosyal mesafeyi koruma ve diğer kurallara uyma davranışı bakımından daha iyi bir durumda olduğunu göstermiştir.

Küresel salgın süreci ile birlikte özellikle bireylerin kaygı durumları ile ilgili değişkenliklerin olduğu da gözlenmektedir. Örneğin hastalığa yakalanma olasılığını arttıran faktörlere sahip olmak (hastalığın yoğunlaştığı yerlere yakın oturmak, risk grubunda olmak), çocuklar, eş, anne-baba gibi başkalarının sorumluluğunu taşımak (Yang ve Ma, 2020), evden çalışma imkânının bulunmaması (Çölgeçen ve Çölgeçen, 2020; Doğan ve Düzel, 2020), bekar olmak ve kadın olmak (Göksu ve Kumcağız, 2020) bireylerin psikolojik iyi oluş halini farklı şekillerde etkilemektedir. Aynı zamanda televizyon ve internet aracılığı ile uzun süreli küresel salgın ile ilgili haberlere maruz kalmak da bireylerin öfke kontrol durumunu olumsuz yönde etkilemektedir (Doğan ve İmamoğlu, 2020). Bu anlamda küresel salgın sürecinde medyanın bilinçsiz kullanımı da özellikle çocuk ve ergenlerin psikolojik iyi oluş hali üzerinde olumsuz etkide bulunmaktadır (Sarman ve ark., 2020).

$\mathrm{Bu}$ faktörlerin yanı sıra yetişkinlerde çocuk bakımı ve evin geçimi ile ilgili ekonomik kaygılar da psikolojik iyi oluş halini olumsuz yönde etkilemektedir. Var olan işini kaybetme ya da her zaman elde ettiği gelirden daha az gelir elde etme, çocuk bakım hizmetlerine erişememe, sağlıkla ilgili yardımlara ulaşamama ve yiyeceklerle ilgili sağlık endişeleri, ebeveynlerin çocukları ile ilişkili olarak kaygılanmalarına daha fazla neden olmaktadır. Aynı zamanda çocukların günlük rutinlerinin bozulması, okul gibi dışarıda vakit geçirdikleri alanların kısıtlanması çeşitli davranışsal ve duygusal sorunlara neden olmaktadır (Godinic ve ark., 2020; Patrick ve ark., 2020).

Küresel salgın öncesinde yaşanan stres faktörleri, COVID-19'a bağlı ekonomik ve sosyal yaşamdaki kesinti ve değişimler, kapatma sırasında genç yetişkinlerin stres düzeyini arttıran etkenler olarak öne çıkmaktadır (Shanahan ve ark., 2020). Bu etkiler sonucunda genç yetişkinlerin düzensiz fiziksel aktivitenin olduğu ya da daha da kötüsü hiç fiziksel etkinliğin olmadığı sedanter bir yaşam tarzını tercih ettikleri görülmektedir. Bu durum COVID-19 dışında bireylerin sağlığını tehdit eden bir risk olarak ortaya çıkmaktadır (Zheng ve ark., 2020). Özellikle daha önce stresli olaylara maruz kalan psikiyatrik geçmişi olan ya da kaygıya eğilimli bireylerin küresel salgın sürecinde psikolojik iyi oluşunun daha fazla olumsuz etkilendiği görülürken, pozitif başa çıkma becerileri sergileyen (Bilge ve Bilge, 2020; Eryılmaz ve Şiraz, 2020), küresel salgın süreci hakkında bilgi edinip kişisel kontrol algısını güçlendiren (Yang ve Ma, 2020), dışa dönük ve deneyime açık kişilik özelliği sergileyen (Modersitzki ve ark., 2020), stresini belli bir düzeyde kontrol edebilen (Altuntaş ve Tekeci, 2020), hareketsiz bir yaşam yerine evde dâhi olsa egzersizi tercih eden (Demir 
ve Çifçi, 2020), psikolojik esnekliğe sahip olan (Dawson ve Golijani-Moghaddam, 2020; Değirmenci, 2020) bireylerin küresel salgın sürecinin zorlukları ile daha iyi başa çıktıkları ve psikolojik iyi oluş halini korudukları gözlenmektedir.

\section{Küresel Salgın Sürecinde Çocuklar, Ergenler ve Genç Yetişkinler}

Küresel salgın sürecinin özellikle çocuk, ergen ve genç yetişkinler üzerindeki etkileri orta yaş ve üzeri yetişkinlere göre daha farklı biçimlerde ortaya çıkabilmektedir. Örneğin Miranda ve arkadaşları (2020), çocuk ve ergenlerin küresel salgın sürecine ilişkin yaptıkları makale tarama çalışmalarında çocukların yüksek düzeyli kaygı, depresyon ve post travmatik semptomlar sergilediklerini ortaya koymuşlardır. Özellikle çocuklar yoğun derecede güven arayış1 içinde oldukları ve arkadaşları ile bir arada olmak istedikleri bir dönemde hem hastalık tehdidi hem de yalnızlık problemi ile karşı karşıya kalmaktadır (Çaykuș ve Mutlu-Çaykuş, 2020) ve bu durum onların duygusal gelişimleri açısından risk teşkil etmektedir. Evirgen-Argın, Özkök-Kayhan ve Erden'in (2020) çalışmasında, anneler 36-77 aylık çocuklarında küresel salgın döneminde, öncesine kıyasla daha fazla ayrılık kaygısı, öfke patlamaları, sinirlilik, huzursuzluk, inatlaşma ve sebepsiz ağlama gibi duygusal tepkiler ile kurallara karşı gelme ve kendisinden istenileni reddetme davranışlarında artış bildirmişlerdir. Aynı çalışmada uyku ve yeme düzenlerinde olumsuz yönde değişiklikler ve rapor edilmiştir.

Benzer şekilde ergenler de hastalık sürecine ilişkin daha hassas, kırılgan özellikler göstermektedir. Çünkü ergenler aynı zamanda yetişkinliğe geçişin getirdiği bazı stresleri de birlikte yaşamaktadır. Özellikle ergen kadınlar ve sosyoekonomik düzeyi düşük ailelerden gelen ergenler küresel salgın sürecinde daha fazla kaygı rapor etmektedirler. Kılınçel ve arkadaşları (2020), 745 ergen ile yaptıkları çalışmada küresel salgın sürecinde ortaya çıkan yalnızlık durumunun ergenlerin kaygı düzeylerini arttırdığını göstermişlerdir. Aynı zamanda daha önce psikiyatrik rahatsızlı̆g 1 olan ya da yakınlarından birinde hastalık görülen bireylerin de daha kolay kaygıya kapıldığı görülmüsstür.

Ergenler dışında, daha önce çalışan ya da üniversite eğitimi alan yani daha önce aktif bir hayatı olan genç yetişkinlerin de yalnızlık ve depresyon düzeyinde belirli bir artış olduğu görülmektedir (Lee ve ark., 2020). Bu bağlamda ergenler ve genç yetişkinlerde bireysel kaygılardan ziyade sosyalleşememe kaygılarının da daha yoğun olabileceği dikkate alınmalıdır (Tekin, 2020). Bu süreçte genç yetişkinlerin sosyal ve ekonomik durumları yaşadıkları stresi, hasta olma riskinden daha fazla etkilemektedir. Özellikle kamu sektöründe çalı̧̧an bireylere nazaran özel sektörde çalışan bireylerin psikolojik iyi oluş düzeyleri olumsuz yönde etkilenmektedir (Çiçek ve Almalı, 2020). Üniversite öğrencileri ise yaşanan küresel salgın nedeniyle aktif yaşamlarını bırakmak zorunda olmak ve belirsiz bir düzende çevrimiçi eğitimlere devam etmek nedeniyle hastalığın kendisinden bağımsız kaygılar da yaşamaktadırlar. Tasso ve arkadaşlarının (2021), çalışmasında 257 üniversite öğrencisi, kendilerinin ve sevdiklerinin hasta olmasından çok korktuklarını, ek olarak uzaktan eğitime geçilmesi ile akademik yüklerinin daha çok artması ve değişen akademik süreçteki belirsizlik nedeniyle kaygı yaşadıklarını belirtmişlerdir.

Yukarıda belirtilen alan yazını bulguları ışığında, bu çalışmada Türkiye'de COVID-19 sürecinde üniversite öğrencilerinde demografik faktörlerin (cinsiyet, sosyoekonomik düzey, annenin eğitim düzeyi ve babanın eğitim düzeyi), sosyal faktörlerin (romantik ilişkinin varlı̆̆ı, sosyal destek, aile üyeleri ile temas, arkadaşlarla temas ve özel kişisel konuları konuşacak yakınlıkta birinin varlığı), akademik faktörlerin (akademik stres, akademik memnuniyet, öğretim elemanları ile ders hakkındaki endişeleri konuşmak için iletişime geçme düzeyi, öğretim elemanları ile psikososyal sorunları konuşmak için iletişime geçme düzeyi, öğrenci danışmanlık birimi ya da sosyal birim ile iletişim düzeyi) ve COVID-19 hastalığı ile ilgili faktörlerin (kronik rahatsızlık, enfeksiyon belirtisi, COVID-19 önlemlerine uyma ve COVID-19 endişesi) psikolojik iyi oluş hali ile ilişkisi incelenmiştir. Araştırma verilerinin virüsün Türkiye'de ilk kez görüldüğü 11 Mart'tan sonra yaklaşık iki ay gibi kısa bir süre içerisinde, COVID-19'a ilişkin belirsizliklerin fazla olduğu ve üniversitelerde eğitim yöntemlerinin oturtulmaya çalış1ldığ olması, küresel bir salgın durumunda verilen ilk psikolojik tepkileri ve bu tepkilerle ilişkili faktörleri ortaya koymak bakımından oldukça önemlidir.

\section{Örneklem}

Yöntem

Araştırmaya Çankırı Karatekin Üniversitesi'nde öğrenim gören ön lisans, lisans ve lisansüstü düzeydeki 378 üniversite öğrencisi katılmıştır. Verilerin toplandığ1 2019-2020 eğitim-öğretim döneminde Çankırı Karatekin Üniversitesine kayıtlı öğrenci sayıs1 13.952'dir (YÖK, b.t.). Bu doğrultuda, araştırmanın örneklem büyüklügü, evren büyüklüğü belli olan durumlarda kullanılan $\mathrm{n}=\left[\mathrm{Nz}^{2} \mathrm{pq}\right] /\left[\mathrm{d}^{2}(\mathrm{~N}-1)+\mathrm{z}^{2} \mathrm{pq}\right]$ formülünü (Daniel, 2005) temel alan çevrimiçi hesaplama aracı kullanılarak hesaplanmıştır (http://www.raosoft.com/samplesize.html). Hesaplama sonucunda 13.952 kişilik evrende $\% 95$ güven aralığında 374 öğrenciden oluşan örneklem büyüklüğünün evreni temsil etme gücü bakımından yeterli olacağı sonucuna ulaşılmıştır. Belirlenen sayıdaki katılımcıya olasılığa dayanmayan 
örnekleme yaklaşımının en yaygın türü olan bulabildiğini örnekleme (convenience sampling) yöntemi kullanılarak ulaşılmıştır (Shaughnessy vd., 2000). Örneklemin evreni temsil etme gücünü arttırmak için anket formu Üniversite Öğrenci İşleri Daire Başkanlığı aracılığı ile kayıtlı tüm öğrencilere e-posta yoluyla gönderilmiştir.

$\mathrm{Bu}$ yolla araştırmaya katılan 378 öğrencinin 294'ü kız, 81'i erkek ve 3'ü diğer cinsiyetten olduğunu belirtmiş̧ir. Yaş ortalaması 21.59 ( $\mathrm{S}=2.54$; yaş aralı̆̆ 18 -45) olan katılımcıların 135 'i (\%35.7) halen düzenli bir ilişkisinin olduğunu, 217'si (\%57.4) bir ilişkisinin olmadığını ve 26'sı (\%6.9) ilişkisinin karmaşı olduğunu bildirmiştir. "COVID-19 sırasında yeterli mali kaynağını var mı? sorusuna katılımcıların \%35.2'si katılıyorum, \%27.5'i kararsızım ve \%37.3'ü katılmıyorum yanıtı vermiştir. Katılımcıların annelerinin \%3.7'si, babalarının \%11.6's1 yükseköğretim; annelerinin \%17.7'si, babalarının \%28.0'1 lise; annelerinin 75.9'u babalarının \%59.3'ü liseden az düzeyde bir eğitime sahiptir.

\section{Veri Toplama Araçları}

Bu çalışmada kullanılan anket, COVID-19 Uluslararası Üniversite Öğrencileri İyilik Hali Çalışması yürütücü ekibi tarafından COVID-19 salgınına özel olarak geliştirilmiştir (Van de Velde vd., 2020). Söz konusu anket yedi alt bölümden ve 67'si normal 10'u filtre olmak üzere toplam 77 sorudan oluşmaktadır. Anketin ilk bölümü (12 normal, 4 filtre soru) öğrencilerin cinsiyeti, yaşı, doğum yeri, anne babalarının eğitimi ve maddi destek alıp almadıkları gibi sosyodemografik bilgilerine odaklanmaktadır. İkinci bölüm (7 normal, 1 filtre soru), katılımcıların eğitim gördükleri bölümler ve eğitimlerinin kaçıncı yılında oldukları vb. eğitimleri ile ilgili sorulardan oluşmaktadır. Üçüncü bölüm (10 normal, 1 filtre soru x 2 [COVID-19 öncesi ve sonras1]) katılımc1ların COVID-19'dan önce ve sonraki mali durumlarını, çevrimiçi veya çevrimdışı derslerde harcadıkları zamanı, yaşadıkları yeri, birlikte yaşadıkları insan sayısını ve sigara tüketimi ve egzersiz yapma gibi sağlık davranışlarını değerlendirmeye yönelik soruları içermektedir. Dördüncü bölüm (11 normal, 2 filtre soru), kendilerinin veya ailelerinin COVID-19 geçirip geçirmedikleri ve geçirdilerse semptomların şiddeti ile ilgili kişiye özel sorulardan oluşmaktadır. Bu bölümde ayrıca katılımcıların kronik bir rahatsızlıklarının olup olmadığı, virüsün kendilerine bulaşma olasılığı hakkındaki algıları ve kişisel olarak enfekte olma ya da bir aile üyesi veya arkadaşın enfekte olmasına ilişkin endişe düzeyleri de değerlendirilmektedir. Beşinci bölüm (18 soru), aile ve arkadaşlarla temas gibi stres kaynakları, sosyal destek ve genel psikolojik iyi oluş hali ile ilgili soruları içermektedir. Altıncı bölüm (11 normal, 1 filtre soru), öğrencilerin üniversite personeli ile ilişkileri, akademik iş yükleri ve virüsten bu yana eğitim kalitesi gibi akademik ve üniversite deneyimlerindeki değişikliklerle ilgili sorulardan oluşmaktadır. Yedinci ve son bölüm (10 soru), öğrencilerin COVID-19 hakkındaki bilgileri ile devletin virüsü ele alış biçimine olan güvenlerini ölçmektedir.

Anket, COVID-19 Uluslararası Üniversite Öğrencileri İyilik Hali araştırmasında yer alan Türkiye'den iki araştırmacı tarafından Türkçeye çevrilmiş ve araştırmaya Türkiye'den katılan diğer araştırmacıların da geribildirimleri doğrultusunda son haline getirilmiştir. Ankette toplam puan alınarak kullanılan üç adet ölçek (COVID-19 Algılanan Endişe Ölçeği, Psikolojik İyilik Hali Ölçeği, Üniversite Hayatı Ölçeği) bulunmaktadır. Ölçme araçlarının geçerlik ve güvenirlik çalışmaları araştırma kapsamında gerçekleştirilmiş ve geçerlik ve güvenirlik değerlerinin yeterli olduğu görülmüştür. Bu bağlamda, COVID-19 Algılanan Endişe Ölçeği için yapılan açımlayıcı faktör analizi sonucunda, varyansın \%58.54'ünü açıklayan (özdeğer $=3.51$ ) tek faktör elde edilmiştir ve ölçeğin Cronbach alfa iç tutarlılık katsayısı .86 olarak bulunmuştur. Psikolojik İyilik Hali Ölçeği için yapılan açımlayıcı faktör analizi sonucunda varyansın \%43.66'sını açıklayan (özdeğer $=6.11$ ) tek faktör elde edilmiştir ve Cronbach alfa iç tutarlılık katsayısı .90 'dır. Son olarak Üniversite Hayatı Ölçeği için yapılan açımlayıcı faktör analizi sonucunda toplam varyansın \%55'ini açıklayan 2 faktör elde edilmiştir. Akademik stres olarak adlandırılan ilk faktör varyansın \%30.24'ünü açıklamaktadır (özdeğer $=2.42$ ) ve Cronbach alfa iç tutarlılık katsayısı ,74'tür. Akademik memnuniyet olarak adlandırılan ikinci faktör ise varyansın \%24.76'sını açıklamaktadır (özdeğer = 1.98) ve Cronbach alfa iç tutarlılık katsayısı .68'dir.

\section{İşlem}

$\mathrm{Bu}$ çalışma, uluslararası bir araştırmanın (COVID-19 Uluslararası Üniversite Öğrencileri İyilik Hali Çalışması) bir parçası olarak gerçekleştirilmiş̧ir. Belçika'daki Antwerp Üniversitesi yürütücülüğünde gerçekleştirilen çalışmaya 26 ülkeden, 12'si Türkiye'den olmak üzere 110 yüksek öğretim kurumu katılmıştır (Van de Velde vd., 2020).

Veri toplama işlemlerine başlamadan önce Çankırı Karatekin Üniversitesi'nden etik kurul onayı alınmıştır (22.04.2020 tarih, 52133317-605-E.9167 sayılı etik kurul kararı). Ardından öğrenciler COVID-19 sürecindeki deneyimleri hakkında çevrimiçi bir ankete katılmaları için e-posta yoluyla davet edilmiştir. Katılımcılar; araştırmanın amacı, araştırmaya katılımın gönüllülük esasına dayalı olduğu ve istedikleri herhangi bir zamanda, neden göstermeden araştırmadan çekilebilecekleri konusunda bilgilendirilmişlerdir. 


\section{Bulgular}

Bulgular kısmında ilk olarak psikolojik iyi oluş hali ile ilişkisi incelenen sosyal, akademik ve COVID-19 hastalığı ile ilgili faktörlere ilişkin betimsel analizlere yer verilmiştir (Demografik değişkenlere ait betimsel istatistiklere örneklem kısmında değinilmiştir). İkinci olarak demografik, sosyal, akademik ve COVID-19 hastalığı ile ilgili faktörlerin psikolojik iyi oluş hali üzerindeki etkileri yapılan Aşamalı Hiyerarşik Regresyon Analizi ile incelenmiştir. Araştırmada değişkenler arasındaki ilişkilerin belirlenmesinde Pearson momentler çarpımı korelasyon katsayısından yararlanılmıştır.

\section{Demografik, Sosyal, Akademik ve COVID-19 Hastalığı ile İlgili Faktörlere İlişkin Betimsel Analiz Sonuçları}

Sosyal faktörler. COVID-19 önlemlerinin uygulanmasindan bu yana aileleriyle daha az (\%37.0), ayn1 (\%35.2) ve daha fazla (\%27.8) temas kurduğunu belirten öğrencilerin oranı genel olarak benzerlik göstermiş̧tir. Bununla birlikte, öğrencilerin büyük çoğunluğu (\%79.6) arkadaşlarıyla temaslarının azaldığını belirtmiştir. Katılımcıların \%80.4'ü yaşamında özel ve kişisel tüm konuları konuşabileceği birisinin olduğunu belirtirken, \%19.6'sı böyle bir kişinin olmadığını belirtmiştir. Katılımcıların belirttikleri sosyal destek puan ortalamaları 11.4'tür ( $\mathrm{S}=3.79$, Ranj=6-24). Düzenli bir romantik ilişkisinin olduğunu belirten katılımcıların oranı \%57.4 iken, düzenli bir romantik ilişkisinin olmadığını belirten katılımcıların oranı \%35.7'dir, \%6.9 katılımcı ilişki durumlarını karmaşık olarak tanımlamıştır.

Akademik faktörler. COVID-19 salgınından önceki dönemle karşılaştırıldığında üniversitelerindeki öğretim elemanları ile derslerle ilgili endişeleri hakkında konuşmak için çok daha az ve daha az iletişim kurduğunu belirten öğrencilerin oran $\% 38.9$, aynı düzeyde iletişim kurduğunu belirten öğrencilerin oranı $\% 25.7$ ve daha fazla ve çok daha fazla diyen öğrencilerin oranı \%25.9'dur. Salgından önceki dönemle karşılaştırıldığında, üniversitelerindeki öğretim elemanları ile psikososyal sorunları hakkında konuşmak için çok daha az ve daha az iletişim kurduğunu belirten öğrencilerin oranı \%44.2, aynı düzeyde iletişim kurduğunu belirten öğrencilerin oranı $\% 14.0$ ve daha fazla ve çok daha fazla iletişim kurduğunu belirten öğrencilerin oranı \%4.5'tir. COVID-19 salgınından bu yana, üniversite danışmanlık birimi ya da sosyal birim ile iletişim kurduğunu belirten öğrencilerin oranı \%13.8 iken, kurmadığını belirten öğrencilerin oranı \%86.2'dir. Üniversite danışmanlık birimi ya da sosyal birim ile iletişim kurduğunu belirten öğrenciler $(\mathrm{N}=52)$, gerekçe olarak en fazla çalışmalar/dersler hakkındaki endişeleri konuşmayı $(\mathrm{N}=47)$ belirtmişlerdir.

COVID-19 hastalı̆̆ı ile ilgili faktörler. Öğrencilerin \%8.2'si kronik bir rahatsızlığının olduğunu belirtirken, \%88.9'u bu tür bir rahatsızlığının olmadığını belirtmiştir. Öğrencilerin \%20.9'u son bir ay içerisinde öksürme, hapşırma veya burun akıntısı gibi belirtilerinin olduğunu, \%66.7'si bu tür belirtilerinin olmadığını, \%12.4'ü ise belirti gösterip göstermediğinden emin olmadığını bildirmiştir. Devlet tarafından uygulanan COVID-19 önlemlerine uyduğunu belirten katılımciların ortalama puanı 8.84 'tür $(S=1.81$, Ranj=0-10). COVID-19 ile ilgili endişe duyduğunu belirten katılımcıların ortalama puanı $29.56(\mathrm{~S}=15.58$, Ranj=0-60) olarak bulunmuştur.

\section{Aşamalı Hiyerarşik Regresyon Analizi Sonuçları}

Hiyerarşik regresyon analizi, dört aşamalı olarak gerçekleştirilmiştir. İlk grupta denkleme demografik değişkenler (cinsiyet, sosyoekonomik düzey, annenin eğitim düzeyi ve babanın eğitim düzeyi), ikinci grupta sosyal faktörler (romantik ilişkinin varlığı, sosyal destek, aile üyeleri ile temas, arkadaşlarla temas ve özel kişisel konuları konuşacak yakınlıkta birinin varlığı), üçüncü grupta akademik faktörler (akademik stres, akademik memnuniyet, öğretim elemanları ile ders hakkındaki endişeleri konuşmak için iletişime geçme düzeyi, ögretim elemanları ile psikososyal sorunları konuşmak için iletişime geçme düzeyi, öğrenci danışmanlık birimi ya da sosyal birim ile iletişim düzeyi) ve son grupta COVID-19 hastalığı ile ilgili faktörler (kronik rahatsızlık, enfeksiyon belirtisi, COVID-19 önlemlerine uyma ve COVID-19 endişesi) dâhil edilmiştir. Farklı cinsel yönelime sahip olduğunu belirten üç katılımcı sayılarının çok yetersiz olması nedeniyle korelasyon ve regresyon analizlerine dâhil edilmemiştir. Regresyon analizi öncesinde araştırmada ele alınan değişkenler arasındaki ilişkiye bakılmıştır. Elde edilen korelasyonlar Tablo 1'de sunulmuştur. 
Tablo 1. Değişkenler Arasındaki Korelasyonlar

\begin{tabular}{|c|c|c|c|c|c|c|c|c|c|c|c|c|c|c|c|c|c|c|}
\hline & 2 & 3 & 4 & 5 & 6 & 7 & 8 & 9 & 10 & 11 & 12 & 13 & 14 & 15 & 16 & 17 & 18 & 19 \\
\hline 1. Cinsiyet & .03 & -.06 & -.08 & .06 & -.05 & .00 & -.08 & $.17 * *$ & .05 & -.06 & .05 & .01 & -.06 & -.00 & $.13 *$ & .08 & .08 & $-.14 * *$ \\
\hline 2.Sosyoekonomik düzey & - & -.04 & .09 & .06 & $.12 *$ & -.04 & -.03 & .10 & $-.14 * *$ & $.15^{* *}$ & -.02 & .02 & .00 & .03 & .07 & -.02 & -.09 & $.24 * *$ \\
\hline 3.Annenin eğitim düzeyi & & - & $.41^{* *}$ & .04 & -.04 & -.02 & -.02 & .00 & -.07 & -.06 & .06 & .05 & $-.12^{*}$ & .01 & -.02 & .05 & .02 & .03 \\
\hline 4. Babanın eğitim düzeyi & & & - & .02 & $.11^{*}$ & .04 & .06 & -.04 & .02 & -.03 & -.01 & .00 & -.07 & -.03 & .08 & .04 & .06 & -.06 \\
\hline 5.Romantik ilişki & & & & - & $.12^{*}$ & -.06 & -.02 & $.20^{* * *}$ & .02 & -.04 & -.09 & -.04 & -.05 & .00 & -.04 & $.11^{*}$ & .06 & .08 \\
\hline 6.Sosyal destek & & & & & - & .01 & .02 & $.17^{* *}$ & .00 & $.14^{* *}$ & .05 & $.14^{* *}$ & .01 & -.05 & .01 & -.02 & -.05 & $.18^{*}$ \\
\hline 7.Aile ile temas & & & & & & - & $.25^{* *}$ & .05 & .02 & -.04 & .04 & -.07 & .05 & -.02 & -.02 & -.03 & .07 & $-.12^{*}$ \\
\hline 8.Arkadaşlar ile temas & & & & & & & - & .06 & .00 & .04 & .06 & -.04 & .07 & .01 & .02 & -.01 & .08 & -.01 \\
\hline 9. Yakın birinin varlığ & & & & & & & & - & .01 & $.11^{*}$ & .03 & .02 & -.02 & -.03 & .07 & .07 & -.01 & $.17^{* *}$ \\
\hline 10.Akademik stres & & & & & & & & & - & $-.21^{* *}$ & -.08 & .00 & -.01 & .05 & .02 & .04 & $.13^{*}$ & $-.28^{* *}$ \\
\hline 11.Akademik memnuniyet & & & & & & & & & & - & $.14^{* *}$ & $.13^{*}$ & -.09 & -.06 & .02 & .08 & -.07 & $.25^{* *}$ \\
\hline 12. Öğretim elemanı ile iletişim (derslerle ilgili) & & & & & & & & & & & - & $.32^{* *}$ & $-.11^{*}$ & .03 & .03 & -.02 & .07 & -.08 \\
\hline 13. Öğretim elemanı ile iletişim (psikososyal sorunlarla ilgili) & & & & & & & & & & & & - & $-.16^{* *}$ & -.01 & -.03 & -.01 & -.05 & .06 \\
\hline 14. Danışmanlık Birimi ile iletişim & & & & & & & & & & & & & - & -.05 & .04 & .05 & $.10^{*}$ & .00 \\
\hline 15. Kronik rahatsızlık & & & & & & & & & & & & & & - & -.01 & .01 & $.12^{*}$ & $-.12^{*}$ \\
\hline 16. Enfeksiyon belirtisi & & & & & & & & & & & & & & & - & .09 & -.02 & .04 \\
\hline 17. COVID-19 önlemlerine uyma & & & & & & & & & & & & & & & & - & .05 & .01 \\
\hline 18. COVID-19 endişe & & & & & & & & & & & & & & & & & - & $-.27^{* *}$ \\
\hline 19. Psikolojik iyi oluş & & & & & & & & & & & & & & & & & & - \\
\hline
\end{tabular}


Tablo 1'de de görüldüğü gibi kadın olmak; daha fazla özel ve kişisel konuları konuşacak yakınlıkta birinin olması ve düşük psikolojik iyi oluş ile ilişkili bulunmuştur. Sonuçlar ayrıca sosyoekonomik düzey arttıkça, sosyal desteğin, akademik memnuniyetin ve iyilik halinin arttığını ve akademik stresin düştüğünü göstermektedir. Anne eğitim düzeyi arttıkça babanın eğitim düzeyi artmakta ve danışmanlık birimi ile iletişime geçme düzeyi azaltmakta iken, babanın eğitim düzeyi arttıkça sosyal destek düzeyi artmaktadır. Düzenli bir romantik ilişki yaşama düzeyi arttıkça, sosyal destek, özel ve kişisel konuları konuşacak yakınlıkta birinin varlığı ve COVID-19 önlemlerine uyma düzeyi artmaktadır. Sosyal destek açısından sonuçlar ise artan sosyal destek algısının kişisel konuları konuşacak yakınlıkta birinin varlı̆̆ psikolojik iyi oluş düzeyindeki artışla ilişkili olduğunu göstermiştir. Aile üyeleri ile temas arttıkça arkadaşlarla temas artmakta ve psikolojik iyi oluş düzeyi düşmektedir. Kişisel konuları konuşacak yakınlıkta birinin varlığında artış ise akademik memnuniyet ve psikolojik iyi oluş düzeyindeki artışla ilişkilidir. Akademik stres artarken akademik memnuniyetin ve psikolojik iyi oluş düzeyinin düştügü ve COVID-19 endişe düzeyinin arttığ 1 görülmektedir. Akademik memnuniyetteki artış ise öğretim elemanı ile hem dersler hem de psikososyal sorunlar hakkında iletişime geçme düzeyinde ve ayrıca psikolojik iyi oluş düzeyinde artışla ilişkili bulunmuştur. Diğer yandan öğretim elemanı ile dersler hakkında iletişime geçme düzeyi arttıkça öğretim elemanı ile psikososyal sorunlar hakkında iletişime geçme düzeyi artmakta ancak danışmanlık birimi ile iletişime geçme düzeyi düşmektedir. Öğretim elemanı ile psikososyal sorunlar hakkında iletişime geçme düzeyindeki artış ise danışmanlık birimi ile iletişime geçme düzeyindeki düşüşle ilişiklidir. Ayrıca danışmanlık birimi ile iletişime geçme düzeyindeki artış COVID-19 endişe düzeyindeki artışla ilişkili bulunmuştur. Son olarak kronik rahatsızlı düzeyi arttıkça COVID-19 endişe düzeyinin arttığı ve psikolojik iyi oluş düzeyinin düştüğ̈̈; COVID-19 endişe düzeyi arttıkça da psikolojik iyi oluş düzeyinin düştüguü görülmektedir.

Üniversite öğrencilerinin COVID-19 sırasındaki psikolojik iyi oluş hallerinin demografik, sosyal, akademik ve COVID-19 hastalığı ile ilgili yordayıcılarını belirlemek için yapılan aşamalı hiyerarşik regresyon analizi sonuçları Tablo 2'de sunulmuştur.

Tablo 2. Üniversite Öğrencilerinin COVID-19 Sırasındaki Psikolojik İyi Oluş Hallerinin Yordayıcılarını Belirlemek İçin Yapılan Aşamalı Hiyerarşik Regresyon Analizi Sonuçları

\begin{tabular}{|c|c|c|c|c|c|c|c|c|}
\hline Değişkenler & $R$ & $R^{2}$ & $\Delta R^{2}$ & $\beta$ & $t$ & $\mathrm{~F}$ & $\Delta F$ & $S d$ \\
\hline Sosyoekonomik düzey & .23 & .05 & .05 & .23 & $4.55^{* * *}$ & $20.71 * * *$ & 20.71 & $1-361$ \\
\hline Cinsiyet & .27 & .07 & .02 & -.14 & $-2.82 * *$ & $14.53 * * *$ & 7.94 & $2-360$ \\
\hline Kişisel konuları konuşacak birinin varlığı & .32 & .10 & .03 & .17 & $3.16^{* *}$ & $13.82 * * *$ & 11.57 & 3-359 \\
\hline Aile ile temas & .35 & .12 & .02 & -.13 & $-2.65 * *$ & $12.29 * * *$ & 7.00 & 4-358 \\
\hline Sosyal destek & .37 & .13 & .01 & .12 & $2.35^{*}$ & $11.06^{* * *}$ & 5.53 & $5-357$ \\
\hline Akademik stres & .45 & .20 & .07 & -.27 & $-5.60 * * *$ & $15.23 * * *$ & 31.34 & $6-356$ \\
\hline Akademik memnuniyet & .47 & .22 & .02 & .12 & $2.54^{* *}$ & $14.17^{* * *}$ & 6.43 & $7-355$ \\
\hline Öğretim elemanı ile iletişim (derslerle ilgili) & .48 & .23 & .01 & -.11 & $-2.30^{*}$ & $13.21 * * *$ & 5.30 & 8-354 \\
\hline COVID-19 Endişe & .51 & .26 & .03 & -.19 & $-4.01 * * *$ & $14.00 * * *$ & 15.88 & $9-353$ \\
\hline
\end{tabular}

${ }^{* p}<.05,{ }^{* *} p<.01,{ }^{* * *} p<.001$.

Öğrencilerin psikolojik iyi oluş puan ortalaması $33.83(\mathrm{~S}=8.08$, Ranj=15-52) olarak bulunmuştur. Tablo 2'de görüldügü gibi, psikolojik iyi oluşun yordayıcısı olarak toplam dokuz değişken denkleme girmiştir. İlk sırada "sosyoekonomik düzey", ikinci sırada "cinsiyet" değişkeninin denkleme girdiği ve bu iki değişkenin toplam varyansın \%7'sini açıkladığı görülmektedir. Üçüncü sırada denkleme "kişisel konuları konuşacak birinin varlı̆̆ı", dördüncü sırada "aile ile temas" ve beşinci sırada "sosyal destek" değişkenlerinin girdiği görülmektedir. Bu değişkenlerin varyansa katkısı \%6'dır ve kendinden önceki değişkenlerle birlikte toplam varyansın \%13'ünü açıklamaktadır. Denkleme altıncı sırada "akademik stres", yedinci sırada "akademik memnuniyet" ve sekizinci sırada "öğretim elemanı ile iletişim (derslerle ilgili)" değişkeninin girdiği görülmektedir. Bu üç değişkenin \%10'luk katkısıyla birlikte açıklanan toplam varyans \%23'e yükselmiştir. Son olarak "COVID-19 endişe" değişkeni modele girmiş ve \%3'lük bir katkıyla kendinden önceki değişkenlerle birlikte toplam varyansın \%26'sını açıklamıştır. Tüm bunlara ek olarak değişkenlerin Beta değerleri incelendiğinde, en yüksek değerlerin "akademik stres" $(\beta=-.27)$ ve "sosyoekonomik düzey" ( $\beta=.23)$ değişkenlerine ait olduğu görülmektedir.

$\mathrm{Bu}$ sonuçlara göre, COVID-19 sırasında üniversite öğrencilerinde sosyoekonomik düzey $(\beta=.23, p<.001)$, özel ve kişisel konularda konuşacak yakınlıkta birinin varlığ $1(\beta=.17, p<.01)$, sosyal destek $(\beta=.12, p<.05)$ ve akademik memnuniyet $(\beta=.12, p<.01)$ arttıkça psikolojik iyi oluş hali artmaktadır. Diğer yandan aile üyeleri ile 
temas $(\beta=-.13, p<.01)$, akademik stres $(\beta=-.27, p<.001)$, öğretim elemanı ile dersler hakkındaki iletişim düzeyi $(\beta$ $=-.11, p<.05)$ ve COVID-19 endişe düzeyi $(\beta=-.19, p<.001)$ arttıkça psikolojik iyi oluş halinin azaldığ 1 görülmektedir. Sonuçlar ayrıca kadın olmanın düşük psikolojik iyi oluşla ilişkili olduğunu göstermiştir $(\beta=-.14, p$ $<.01)$.

\section{Tartışma}

Çalışma kapsamında öğrencilerin psikolojik iyi oluş düzeyleri, demografik, sosyal, akademik ve hastalıkla ilişkili değişkenler bağlamında ele alınmıştır. Bireylerin psikolojik iyi oluş düzeyleri bu değişkenler kapsamında tek tek ayrı başlıklar halinde tartışılmıştır.

\section{Cinsiyet Bağlamında Küresel Salgın Sürecinde Psikolojik İyi Oluş}

Küresel salgın sürecinde üniversite öğrencilerinin psikolojik iyi oluş halinin cinsiyetle ilişikli olduğu görülmüştür. Buna göre kadın olmak düşük psikolojik iyi oluş ile ilişkilidir. Yapılan diğer bazı çalışmalar da salgın, doğal afet vb. durumlarda kadınların erkeklere göre daha fazla kaygı yaşadıklarını göstermiştir (Barber ve Odean, 2001; Fujita ve ark., 1991; Kandemir, 2020; Kring ve Gordon, 1998; Liu ve ark., 2020; Niederle ve Vesterlund, 2007; Rodriguez-Ray ve ark., 2020; Sturman, 2020; Wenham ve ark., 2020). Öte yandan, küresel salgın sürecinde psikolojik iyi oluşa ilişkin herhangi bir cinsiyet farklılığı bulmayan (Çetin ve Anuk, 2020; Güzel, 2020; İnan ve Alibwaini, 2020) ya da erkeklerin daha fazla kaygı yaşadığını gösteren (Doğan ve Düzel, 2020) bazı çalışmalar da mevcuttur.

Galasso ve arkadaşları (2020), kadınların küresel salgının ciddiyeti ile ilgili daha fazla farkındalık sahibi olduklarını ifade etmektedir. Bu durumda da kadınlar erkeklere oranla kendilerini daha fazla tehdit altında hissetmekte ve daha az psikolojik iyi oluş bildirmektedirler. Fakat bu durum psikolojik iyi oluşu olumsuz etkilemesine rağmen, küresel salgın ile ilgili tedbirleri almada kadınların daha dikkatli olmasına neden olmaktadır (Galasso ve ark., 2020). Örneğin Lerner ve arkadaşları (2003), erkeklerin tehdit durumlarında daha fazla öfke tepkisi sergilerken kadınların daha tedbirli ve kararlarında daha sağduyulu olduklarını belirtmektedir. Bu anlamda küresel salgın sürecinde kadınlar erkeklere oranla daha çok psikolojik destek ararken, erkeklerin daha fazla fiziksel sağlik destekleri ile ilişkili süreçlere odaklandıkları görülmektedir. $\mathrm{Bu}$ durum kadınların küresel salgın sürecinde duygusal anlamda daha fazla zorlandıklarını fakat tedbirler anlamında daha hassas olduklarını göstermektedir (Song ve ark., 2020).

\section{Sosyoekonomik Faktörler ve Küresel Salgın Sürecinde Psikolojik İyi Oluş}

Sosyoekonomik düzey ile psikolojik iyi oluş arasında anlamlı bir ilişki bulunmuştur. Öğrencilerin sosyoekonomik durumları artıkça psikolojik iyi oluş düzeylerinin arttığı görülmektedir. Aslında bu beklendik bir sonuçtur. Küresel salgın dünyada ve ülkemizde, birçok iş yerinin kapanmasına, personelin işten çıkarılmasına ya da zorunlu ücretsiz izne gönderilmesine neden olmuştur. İş kaybı üniversite öğrencileri ile doğrudan ilişkili gibi görünmese bile, ailelerindeki çalışan bireylerin böyle bir risk ile karşı karşıya kalması ve tüm ailenin bundan etkilenmesi durumu kaçınılmazdır çünkü ülkemizde üniversite öğrencilerinin birçoğu ailelerine maddi olarak bağımlıdırlar. Özellikle ekonomik açıdan güçlü olmayan ülkelerde sosyoekonomik durumu iyi olmayan bireylerin sosyal hayattan izolasyonun yanı sıra eğitim imkânlarına erişme ve çalışmak için akademik kaynakları elde etme bakımından da sorun yaşayacakları çok açıktır (Bodrud-Doza ve ark., 2020). Çünkü bireylerin ekonomik durumlarının kötüye gitmesi, aynı zamanda sosyal etkinlik düzeyleri, boş zaman etkinlikleri gibi davranışlara da yansımakta ve buna bağlı olarak da bireylerin psikolojik iyi oluş düzeylerini olumsuz etkilenmektedir (Kanık ve ark., 2020; Öztürk ve ark., 2020; Sanderson ve ark., 2020). Bu nedenle küresel salgın sürecinin psikolojik olarak olumsuz etkilerini azaltmak için ekonomik anlamda zorluklar yaşayan bireylere gerekli desteklerin verilmesinin önemli olduğu görülmektedir. Fakat çalışma bulguları sosyo-ekonomik düzey bağlamında değerlendirilirken katılımcı sayısının kısıtlı olduğu dikkate alınmalıdır.

\section{Küresel Salgın Sürecinde Sosyal Hayat ve Psikolojik İyi Oluş}

Çalışmada üniversite öğrencilerinin psikolojik iyi oluş düzeyi ile ilişkisi incelenen bir diğer değişken, kapanma sürecinde sosyal hayatın değişimidir. Elde edilen bulgulara göre aile ile temas arttıkça, bireylerin psikolojik iyi oluş düzeyleri azalmaktadır. Bu sonuç, diğer bazı çalışma sonuçlarıyla da tutarlıdır (Tasso ve ark., 2021). Küresel salgın ile birlikte ekonomik zorluklar, okul yaşantısının eve taşınması, günlük rutinlerdeki değişmeler, aile üyelerinin özgürlüklerinin kısıtlanmasına yol açmıştır. Özellikle başka bir şehirde okumanın getirdiği bağımsızlığa alışan genç yetişkinler ailelerinin yanına geri dönmüş, hem okul sorumluluklarını yerine getirmeye çalışmış hem de yeniden ailelerinin kısıtlamaları ile karşı karşıya kalmışlardır. Bu durumda üniversite öğrencilerinin iyi oluş düzeylerinin düşmesi anlaş11ır görünmektedir (Karaca ve ark., 2020; Perrin ve ark., 2009; Prime ve ark., 2020).

Çalışma sonuçları, kişisel ve özel konuları konuşacak birinin varlığının ve artan sosyal desteğin yüksek düzeyde psikolojik iyi oluş hali ile ilişkili olduğunu göstermiştir. Bununla birlikte, çalışmamızda katılımcıların yaklaşık dörtte biri yaşamlarında özel ve kişisel konuları konuşabilecek yakınlıkta birisinin olmadığını belirtmiştir. 
Ayrıca tüm katılımcıların algıladıkları sosyal destek puanı ortalamanın altında bulunmuştur. Bu bulgular, küresel salgın sırasında sosyal desteğin psikolojik iyi oluş üzerindeki rolünü ortaya koymaktadır. Kapanmalar sırasında ortaya çıkan sosyalleşme eksikliklerinden olumsuz etkilenen bireyler için bu destek sistemleri daha fazla öneme sahiptir. Salgın sürecinde gençlerin yüz yüze ya da çevrimiçi paylaşım yapabildikleri yakın bir arkadaşa sahip olması psikolojik iyi oluşlarına olumlu yönde etkilemektedir. Bu bulgular çok sayıda çalışma bulgusuyla da tutarlıdır (Çetin ve Anuk, 2020; Emiral ve ark., 2020; Hawryluck ve ark., 2004; Lee ve ark., 2020; Özmete ve Pak, 2020; RodriguezRey ve ark., 2020; Y1ldırım ve ark., 2021).

\section{Psikolojik İyi Oluş Hali ve Akademik Faktörler}

Çalışmamızın bulguları, COVID-19 ile ilgili endişelerini üniversite birimleri ile konuşmayı tercih eden öğrencilerin oranının oldukça düşük olduğunu göstermektedir. Aynı zamanda üniversite öğrencilerinin akademik memnuniyet düzeyi arttıkça ve akademik stres düzeyi düştükçe psikolojik iyi oluş hali puanları yükselmektedir. Bu bulgular başka çalışmaların bulgularıyla da tutarlılık göstermektedir. Örneğin Tasso ve arkadaşları (2021), uzaktan eğitime geçilmesi ile öğrencilerin akademik yüklerinin daha çok arttığını ve değişen akademik süreçteki belirsizlik nedeniyle kaygı yaşadıklarını belirtmişlerdir. Irawan ve arkadaşları (2020), üniversite öğrencilerinin ilk birkaç haftadan sonra çevrimiçi eğitimden sıkılmaya başladıklarını, özellikle ebeveynleri düşük gelire sahip öğrencilerin çevrimiçi eğitimin maliyeti nedeniyle kaygılandıklarını, çok fazla değerlendirilmenin öğrencilerin duygu durumunda değişimlere neden olduğunu ve öğrenciler tarafından çevrimiçi eğitimin etkisiz algılandığını bulgulamaktadır. Uzaktan eğitimin getirdiği tüm bu sıkıntılar ile beraberindeki akademik stres ve memnuniyetsizlik üniversite öğrencilerinin psikolojik iyilik halini olumsuz etkiliyor görünmektedir.

Araştırmamızda beklenmedik bir şekilde öğrencilerin öğretim elemanları ile dersler hakkında konuşmasının psikolojik iyi oluş düzeylerini düşürdüğü bulunmuştur. $\mathrm{Bu}$ sonuç öğretim elemanları ile iletişimin, öğrencilerin yaşadıkları akademik stres ile iyi oluş halleri arasındaki ilişkide aracı bir rolünün olabileceğini akla getirmektedir. Akademik stresin artması öğrencileri öğretim elemanlarıyla daha fazla iletişime geçmeye itmiş olabilir ancak benzer bir belirsizliğin akademisyenler için de söz konusu olduğu düşünüldüğünde öğretim elemanı ile konuşma tek başına akademik stres ile öğrencilerin iyi oluş halleri arasındaki ilişkide koruyucu bir faktör olarak ortaya çıkmamış olabilir.

\section{COVID-19 Hastalığı ile İlgili Faktörler, Endişe ve Psikolojik İyi Oluş Hali}

Öğrencilerin COVID-19 rahatsızlığına ilişkin yaşadıkları endişenin de psikolojik iyi oluş ile ilişkili olduğu görülmüştür. Rahatsızlığa yakalanma konusunda endişe arttıkça bireylerin psikolojik iyi oluş düzeyi de düşmektedir. Bu durum yapılan diğer çalışma sonuçlarıyla tutarlıdır (Altuntaş ve Tekeci; 2020; Ekiz ve ark., 2020, Tasso ve ark., 2021). Genç yetişkinlerde küresel salgın süreci içinde yaşanan stresin kaynaklarını; süreçle ilgili belirsizlik, sosyal izolasyon ve sağlıkla ilgili yaşanan endişeler oluşturmaktadır (Shanahan ve ark., 2020; Tekin, 2020). Aslında genç yetişkinler hastalığa yakalanma konusunda daha az risk taşımalarına rağmen Lopez-Nunez ve arkadaşları (2020), otuz yaş altı bireylerin kaygı ve depresyon düzeylerini daha yüksek bulmuştur. Bunun bir sebebi genç yetişkinlerin kısıtlamalar karşısında daha fazla televizyon ve sosyal medya karşısında vakit geçirmeleri, küresel salgın haberlerine ve hastalıkla ilgili aile bireyleri tarafından sürekli telkine maruz kalmaları olabilir (Zheng ve ark., 2020).

Özellikle daha önce psikolojik rahatsızlık geçmişi olan, küresel salgın sürecinde yakınlarının, arkadaşlarının vefatlarına şahit olan genç yetişkinlerin endişe, kaygı ve stres düzeyleri diğer genç yetişkinlere göre daha fazladır (Liu ve ark., 2020). Fakat böyle bir geçmişi olsun olmasın salgın süreci, gençlerin uyku süreçlerini olumsuz etkilemektedir (Hyun ve ark., 2021). Bu kaygıyı arttıran en önemli unsurlardan bir diğeri doğru kaynaklardan bilgi alınmamasıdır. Sosyal medya ve internet kullanımı genç yetişkinlerin yalnızlık duygusuna olumlu etki yapmakta fakat yanlış bilgi kaynakları nedeniyle endişe düzeylerini de arttırmaktadır (Emiral ve ark., 2020). Aynı zamanda özellikle çocuklar, ergenler ve genç yetişkinlerin sosyal bağlarının arttırılması, evde yapabilecekleri boş zaman etkinlikleri konusunda yönlendirilmesi, fiziksel etkinlik düzeylerinin arttırılması yaşadıkları endişelerin azalmasına ve doğal olarak psikolojik iyi oluş düzeylerinin artmasına yardımcı olacaktır (Aşkın ve ark., 2020; Demir ve Çifçi, 2020; Öztürk ve ark., 2020). Bunun dışında risk altındaki genç yetişkinlerin belirlenerek gerekli önleyici çalışmaların yapılması büyük önem taşımaktadır.

\section{Sonuç}

Küresel salgın sürecinin genç yetişkin bireylerin psikolojik iyi oluş halleri üzerinde önemli etkileri olduğu görülmektedir. Üniversite öğrencilerinin psikolojik iyi oluş halleri ile ilişkili faktörleri çok yönlü olarak ele alan bu çalışmada, aile yanında geçirilen zamanın artmasının, COVID-19 ile ilgili endişenin, akademik stresin ve kadın olmanın psikolojik iyi oluş hali için risk faktörleri; algılanan yüksek sosyoekonomik düzeyin, sosyal desteğin, yüksek akademik memnuniyetin ve özel ve kişisel konularda konuşacak yakınlıkta birinin varlığının ise koruyucu faktörler olduğu gösterilmiştir.Özellikle sosyoekonomik düzeyi düşük olan bireylerin, kadınların, endişe düzeyi yüksek olan 
kişilerin ve sosyal destek sistemleri zayıf olan bireylerin psikolojik iyi oluş düzeylerinin bu süreçten olumsuz etkilendiği görülmektedir. Bu nedenle bireylerin farklı psikolojik problemlerle karşılaşmaması açısından öncelikle maddi konularda ortaya çıkan eşitsizlikleri giderecek çalışmalara ağırlık verilmelidir. İkinci olarak toplumda akıl sağlığ hizmeti veren resmi ve gönüllü kuruluşlarla iş birliğine geçilerek önleyici psiko-eğitimlerin sistemli hale getirilmesi önemli görünmektedir. Diğer yandan öğrencilerin değişen eğitim süreçlerine uyumunu kolaylaştıracak uygulamaların hayata geçirilmesi, COVID-19'un üniversite öğrencileri üzerindeki akademik faktörlere bağlı etkilerinin en aza indirilmesi konusunda yardımcı olacaktır. Özellikle eğitime ulaşma imkânı olmayan bireyler için acil çözümler üretilmelidir. Bu çözümler elektronik imkânların sağlanmasının yanı sıra akademik kaynaklara ücretsiz ulaşabilecekleri sistemlerin de kurulmasıyla mümkün olacaktır.

Çalışmamız küresel salgının ilk dönemlerindeki psikolojik etkileri görebilmek adına önemli bulgular ortaya koymuş olmakla birlikte, kesitsel bir çalışma olması ve belirli bir örneklemle sınırlı kalması bulguların genellenebilirliğini azaltmaktadır. Devam eden etkileri görebilmek adına boylamsal çalışmaların yapılması çok büyük önem taşımaktadır.

\section{Araştırmacıların Katkı Oranı}

Yazarlar çalışmaya eşit oranda katkı sunmuşlardır.

\section{Destek ve Teșekkür}

Yazarlar çalışma için herhangi bir finansal destek almamışlardır.

\section{Çıkar Çatıșması}

Yazarlar çalışmada herhangi bir çıkar çatışmasının bulunmadığını beyan etmişlerdir. 


\section{Kaynakça / References}

Altuntaş, O., \& Tekeci, Y. (2020). Effect of COVID-19 on perceived stress, coping skills, self-control and self-management skills. Research Square, https://doi.org/10.21203/rs.3.rs-48393/v1

Aşkın, R., Bozkurt, Y, \& Zeybek, Z. (2020). COVID-19 pandemisi: Psikolojik etkileri ve terapötik müdahaleler. İstanbul Ticaret Üniversitesi Sosyal Bilimler Dergisi, 19(37), 304-318.

Barber, B. M., \& Odean, T. (2001). Boys will be boys: Gender, overconfidence, and common stock investment. The Quarterly Journal of Economics, 116(1), 261-292.

Bilge, Y., \& Bilge, Y. (2020). Koronovirüs salgını ve sosyal izolasyonun psikolojik semptomlar üzerindeki etkilerinin psikolojik sağlamlık ve stresle baş etme tarzları açısından incelenmesi. Klinik Psikiyatri, 23(Ek 1), 38-51.

Bodrud-Doza, M., Shammi, M., Bahlman, L., Islam, A. R., \& Rahman, M. M. (2020). Psychosocial and socio-economic crisis in Bangladesh due to COVID-19 pandemic: A perception-based assessment. Froniters in Puplic Health, 8, 341-358.

Çaykuş, E. T., \& Mutlu-Çaykuş, T. (2020). COVID-19 pandemi sürecinde çocukların psikolojik dayanıklılığını güçlendirme yolları: Ailelere, öğretmenlere ve ruh sağlığı uzmanlarına öneriler. Avrasya Sosyal ve Ekonomi Araştırmaları Dergisi, 7(5), 95-113.

Çetin, C., \& Anuk, Ö. (2020). COVID-19 pandemi sürecinde yalnızlık ve psikolojik dayanıklılık: Bir kamu üniversitesi öğrencileri örneklemi. Avrasya Sosyal ve Ekonomi Araştırmaları Dergisi, 7(5), 170-189.

Çiçek, B., \& Almalı, V. (2020). COVID-19 pandemi sürecinde kaygı öz-yeterlilik ve psikolojik iyi oluş arasındaki ilişki: Özel sektör ve kamu çalışanları karşılaştırması. Turkish Studies, 15(4), 241-260.

Çölgeçen, Y., \& Çölgeçen, H. (2020). COVID-19 pandemisine bağlı yaşanan kaygı düzeylerinin değerlendirilmesi: Türkiye örneği. Tutkish Studies, 15(4), 261-275.

Daniel, W. W. (2005). Biostatistics: A Foundation for Analysis in the Health Sciences (8th edition). New York: John Wiley \& Sons.

Dawson, D. L., \& Golijani-Moghaddam, N. (2020). COVID-19: Psychological flexibility, coping, mental health, and wellbeing in the UK during the pandemic. Journal of Contextual Behavioral Sicence, 17, 126-134.

Değirmenci, B. (2020). COVID-19 algısının sosyal endişeler üzerindeki etkisinde "sıkıntıya dayanmanın" aracılık etkisinin incelenmesi. Balkan ve Yakın Doğu Sosyal Bilimler Dergisi, 6(özel sayı), 83-93.

Demir, A., \& Çifçi, F. (2020). COVID-19 pandemi sürecinde egzersizin lise öğrencilerinin psikolojik sağlamlık düzeylerine etkisinin incelenmesi. Spormetre: Beden Eğitimi ve Spor Bilimleri Dergisi, 18(3), 169-179.

Diener, E., \& Diener, C. (1996). Most people are happy. Psychological Science, 7(3), 181-185.

Doğan, M. M., \& Düzel, B. (2020). COVID-19 özelinde korku-kaygı düzeyleri. Turkish Studies, 15(4), $739-752$.

Doğan, E. ve İmamoğlu, O. (2020). Üniversite eğitimi alan öğrencilerin koronavirüs salgını sürecinde sabır eğilimlerinin araştırılması. Turkish Studies, 15(4), 315-324.

Ekiz, T., Ilıman, E., \& Dönmez, E. (2020). Bireylerin sağlık anksiyetesi düzeyleri ile COVID-19 salgını kontrol algısının karşılaştırılması. Uluslararası Sağlık Yönetimi ve Stratejileri Araştırma Dergisi, 6(1), 139-154.

Elbay, R. Y., Kurtulmuş, A., Arpacioğlu, S., \& Karadere, E. (2020). Depression, anxiety, stress levels of physicians and associated factors in COVID-19 pandemics. Psychiatry Research, 290, 113-130. https://doi.org/10.1016/j.psychres.2020.113130.

Emiral, E., Çevik, Z. A., \& Gülümser, Ş. (2020). COVID-19 pandemisi ve intihar. ESTÜDAM Halk Să̆llğg Dergisi, 5(COVID-19 özel sayıs1), 138-147.

Eryılmaz, A., \& Şiraz, M. F. (2020). COVID-19 bağlamında kötümserliği ortaya çıkaran olaylarla-durumlarla başa çıkma ve ergen öznel iyi oluşu ile ilişkisinin incelenmesi. İstanbul Ticaret Üniversitesi Sosyal Bilimler Dergisi, 19(37), $292-303$. 
Evirgen-Argın, N., Özkök-Kayhan, E., \& Erden, G. (2020). COVID-19 salgınının ve karantina sürecinin okul öncesi dönemdeki çocuklardaki duygusal ve davranışsal etkilerinin araştırılması. (C. Ş. Çukur \& Ö. Yalçınkaya-Alkar), Pandemi psikolojisi içinde (ss. 17-26). Ankara: Türkiye Klinikleri.

Fujita, F., Diener, E., \& Sandvik, E. (1991). Gender differences in negative affect and well-being: The case for emotional intensity. Journal of Personality and Social Psychology, 61(3), 427-434.

Galasso, V., Pons, V., Profeta, P., Becher, M., Brouard, S., \& Foucault, M. (2020). Gender differences in COVID-19 attitudes and behavior: Panel evidence from eight countries. PNAS, 117(44), 27285-27291.

Garfin, D. R., Holman, E. A., \& Silver, R. C. (2015). Cumulative exposure to prior collective trauma and acute stress responses to the Boston Marathon Bombings. Psychological Science, 26(6), 675-683.

Godinic, D., Obrenovic, B., \& Khudaykulov, A. (2020). Effect of economic uncertainty on mental health in the COVID-19 pandemic context: Social identity disturbance, job uncertainty and psychological well-being model. International Journal of Innovation and Economic Development, 6(1), 61-74.

Göksu, Ö., \& Kumcağız, H. (2020). COVID-19 salgınında bireylerde algılanan stres düzeyi ve kaygı düzeyleri. Turkish Studies, $15(4), 463-479$.

Güzel, H. Ş. (2020). Yeni koronavirüs hastalığı 2019'un (COVID-19) aile bağlamında ergenler üzerindeki psikolojik etkileri. C. Ş. Çukur, \& Ö. A. Yalçınkaya içinde, Pandemi Psikolojisi (s. 27-33). Ankara: Türkiye Klinikleri.

Hawryluck, L., Gold, W. L., Robinson, S., Pogorski, S., Galea, S., \& Styra, R. (2004). SARS control and psychological effects of quarantine. Emerging Infectious Diseases, 10(7), 1206-1212.

Hyun, S., Hahm, H. C., Wong, G. T., Zhang, E., \& Liu, C. H. (2021). Psychological correlates of poor sleep quality among U.S. young adults during the COVID-19 pandemic. Sleep Medicine, 78, 51-56.

Irawan, A. W., Dwisona, D., \& Lestari, M. (2020). Psychological impacts of students on online learning during the pandemic COVID-19. KONSELI: Jurnal Bimbingan dan Konseling (E-Journal), 7(1), 53-60.

İnan, E., \& Alibwaini, I. (2020). Pandemi sürecinde iyi oluşu belirleyen faktörler. C. Ş. Çukur \& Ö. A. Yalçınkaya (Ed.), Pandemi Psikolojisi içinde (ss. 45-50). Ankara: Türkiye Klinikleri.

Jehn, M., Kim, Y., Bradley, B., \& Lant, T. (2011). Community knowledge, risk perception, and preparedness for the 2009 influenza A/H1N1 pandemic. Journal of Public Health Management and Practice, 17(5), 431-438.

Kandemir, F. (2020). Bazı demografik değişkenler bağlamında COVID-19 pandemi neslinin dindarlık ve ölüm kaygısı ilişsisi üzerine ampirik bir araştırma. Tokat Ilmiyat Dergisi, 8(1), 99-129.

Kanık, B., Solak, N., \& Uluğ, Ö. M. (2020). Koronavirüs pandemisi sürecinde sosyoekonomik düzeyin ve ekonomik kaygıların psikolojik iyi oluştaki rolü. C. Ş. Çukur, \& Ö. A. Yalçınkaya (Ed.), Pandemi Psikolojisi içinde (ss. 51-58). Ankara: Türkiye Klinikleri.

Karaca, N. H., Uzun, H., \& Metin, Ş. (2020). The relationship between the motor creativity and peer play behaviors of preschool children and the factors affecting this relationship. Thinking Skills and Creativity, 38. https://doi.org/10.1016/j.tsc.2020.100716

Kedraka, K., \& Kaltsidis, C. (2020). Effects of the COVID-19 pandemic on university pedagogy: Students' experiences and considerations. European Journal of Education Studies, 7(8), 17-30.

Kılınçel, Ş., Kııınçel, O., Muratdağı, G., Aydın, A., \& Usta, M. B. (2020). Factors affecting the anxiety levels of adolescents in home-quarantine during COVID-19 pandemic in Turkey. Asia-Pacific Psychiatry. https://doi.org/10.1111/appy.12406.

Kring, A. M., \& Gordon, A. H. (1998). Sex differences in emotion: Expression, experience and physiology. Journal of Personality and Social Psychology, 74(3), 686-703.

Lee, C. M., Cadigan, J. M., \& Rhew, I. C. (2020). Increases in loneliness among young adults during the COVID-19 pandemic and association with increases in mental health problems. Journal of Adolescent Health, 67(5), 714-717. 
Leggat, P. A., Brown, L. H., \& Speare, R. (2010). Level of concern and precaution taking among Australians regarding travel during pandemic (H1N1) 2009: Results from the 2009 Queensland Social Survey. Journal of Travel Medicine, 17(5), 291-295.

Lerner, J. S., Gonzalez, R. M., Small, D. A., \& Fischhoff, B. (2003). Effect of fear and anger on perceived risks of terrorism: A national field experiment. Psychological Science, 14(2), 144-150.

Liu, N., Zhang, F., Wei, C., Jia, Y., Shang, Z., Sun, L., . . Liu, W. (2020). Prevalence and predictors of PTSS during COVID-19 outbreak in China hardest-hit areas: Gender differences matter. Psychiatry Research, 287. https://doi.org/10.1016/j.psychres.2020.112921

Lopez-Nunez, M. I., Diaz-Morales, J. F., \& Aparicio-Garcia, M. E. (2021). Individual differences, personality, social, family and work variables on mental health during COVID-19 outbreak in Spain. Personality and Individual Differences, 172. https://doi.org/10.1016/j.paid.2020.110562.

McKibbin, W., \& Fernando, R. (2020). The economic impact of COVID-19. Baldwin . B. W. R. ve di Mauro içinde, Economics in the Time of COVID-19 (s. 1-55). London: Centre for Economic Policy Research.

Miranda, D. M., Athanasio, B. D., Oliveira, A. C., \& Simoes-e-Silva, A. C. (2020). How is COVID-19 pandemic impacting mental health of children and adolescents? International Journal of Disaster Risk Reduction, 51, https://doi.org/10.1016/j.ijdrr.2020.101845.

Modersitzki, N., Phan, L. V., Kuper, N., \& Rauthmann, J. F. (2020). Who is impacted? Personality predicts individual differences in psychological consequences of the COVID-19 pandemic in Germany. Social Psychological and Personality Science. https://doi.org/10.1177/1948550620952576.

Morgül, E., Bener, A., Atak, M., Akyel, S., Aktaş, S., Bhugra, D., . . . Jordan, T. R. (2020). COVID-19 pandemic and psychological fatigue in Turkey. The International Journal of Social Psychiatry, 67(2) 128-135.

Niederle, M., \& Vesterlund, L. (2007). Do women shy away from competition? So men complete too much? The Quarterly Journal of Economics, 122(3), 1067-1101.

Özmete, E., \& Pak, M. (2020). The Relationship between Anxiety Levels and Perceived Social Support during the Pandemic of COVID-19 in Turkey. Social Work in Puplic Health, 35(7), 603-616.

Öztürk, İ., Akalın, S., Özgüner, İ., \& Şakiroğlu, M. (2020). COVID-19 salgının ve karantinanın psikolojik etkileri. Turkish Studies, 15(4), 885-903.

Patrick, S. W., Henkhaus, L. E., Zickafoose, J. S., Lovell, K., Halvorson, A., Loch, S., . . Davis, M. M. (2020). Well-being of parents and children during the COVID-19 pandemic: A national survey. Pediatrics, 146(4). https://doi.org/10.1542/peds.2020-016824.

Perrin, P. C., McCabe, O. L., Everly, G. S., \& Links, J. M. (2009). Preparing for an influenza pandemic: Mental health considerations. Prehospital And Disaster Medicine, 24 (3), 223-230.

Prime, H., Browne, D. T., \& Wade, M. (2020). Risk and Resilience in Family Well-Being During theCOVID-19 Pandemic. American Psychologist, 75(5), 631-643.

Rodriguez-Ray, R., Garrido-Hernansaiz, H., \& Collado, S. (2020). Psychological impact and associated factors during the initial stage of the Coronavirüs (COVID-19) pandemic among the general popülation of Spain. Frontiers in Psychology, 11, $1540-153$

Salehinejad, M. A., Majidinezhad, M., E.Ghanavati, Kouestanian, S., Vicario, C. M., Nitsche, M. A., \& Nejati, V. (2020). Negative impact of COVID-19 pandemic on sleep quantitative parameters, quality, and circadian alignment: Implications for health and psychological well-being. EXCLI Journal, 19, 1297-1308.

Sanderson, W. C., Arunagiri, V., Funk, A. P., Ginsburg, K. L., Krychiw, J. K., Limowski, A. R., Stout, Z. (2020). The nature and treatment of pandemic-related psychological distress. Journal of Contemporary Psychotherapy, 50, $251-263$.

Sarman, A., Tuncay, S., \& Sarman, E. (2020). COVID-19 pandemi sürecinde medyanın 3-18 yaş arasındaki çocuklar üzerindeki olumsuz psikolojik etkisinin önlenmesi. Van Sağlık Bilimleri Dergisi, 13 (Ö̈zel Sayl), 69-75. 
Satıcı, B., Sarıcalı, M., Satıcı, S. A., \& Griffiths, M. D. (2020). In tolerance of uncertainty and mental wellbeing: Serial mediation by rumination and fear of COVID-19. International Journal of Mental Health and Addiction. https://doi.org/10.1007/s11469-020-00305-0.

Setbon, M., Pape, M. L., Letroublon, C., Caille-Brillet, A. L., \& Raude, J. (2011). The public's preventive strategies in response to the pandemic influenza A/H1N1 in France: Distribution and determinants. Preventive Medicine, 52(2), 178-181.

Shanahan, L., Steinhoff, A., Bechtiger, L., Murray, A. L., Nivette, A., Hepp, U., Ribeaud, D., Eisner, M. (2020). Emotional distress in young adults during the COVID-19 pandemic: evidence of risk and resilience from a longitudinal cohort study. Psychological Medicine, 1-10. https://doi.org/10.1017/S003329172000241X.

Shaughnessy, J. J., Zechmeister, E. B. ve Zechmeister, J. S. (2000). Research Methods in Psychology (10th Edition). McGrawHill.

Smith, R. D., Keogh-Brown, M. R., \& Barnett, T. (2011). Estimating the economic impact of pandemic influenza: An application of the computable general equilibrium model to the UK. Social Science \& Medicine, 73(2), 235-244.

Sonderskov, K. M., Dinesen, P. T., Santini, Z. I., \& Ostergaard, S. D. (2020). The depressive state of Denmark during the COVID-19 pandemic. Acta Neuropsychiatra, 32(4), 226-228.

Song, K., Xu, R., Stratton, T. D., Kavcic, V., Luo, D., Hou, F., Jiang, Y. (2020). Sex differences and psychological stress: Responses to the COVID-19 epidemic in China. BMC Pubic Health. 21(79). https://doi.org/10.1186/s12889-020-10085$\mathrm{W}$

Sturman, E. D. (2020). Coping with COVID-19: Resilience and psychological well-being in the midst of a pandemic. Journal of Social and Clinical Pscyhology, 39(7), 561-570.

Tasso, A.F., Hisli Şahin, N., \& San Roman, G.J. (2021). COVID-19 disruption on college students: cademic and socioemotional implicaions. Psychological Trauma: Theory Reserach, Practice, and Policy, 13(1), 9-15.

Tekin, E. (2020). COVID-19 kaygısının motivasyon üzerindeki etkisi: Z kuşağı üzerine bir araştırma. Turkish Studies, 15(4), 1129-1145.

Thompson, R. R., Garfin, D. R., \& Holman, E. A. (2017). Distress, worry, and functioning following a global health crisis: A national study of Americans' responses to Ebola. Clinical Psychological Science, 5(3), 513-521.

Van de Velde, S., Buffel, V., Bracke, P., Van Hal, G., Somogyi, N. M., Willems, B., ... \& C19 ISWS consortium\#. (2020). The COVID-19 International Student Well-being Study. Scandinavian Journal of Public Health, 49(1), 114-122.

Wenham, C., Smith, J., Morgan, R., Gender and COVID-19 Working Group (2020). COVID-19: the gendered impacts of the outbreak. Lancet, 14(395), 846-848.

WHO. (2021). Coronavirus disease (COVID-19) Situation. Erişim [12.01.2021]: https://www.who.int/

Wong, L. P., \& Sam, I.-C. (2010). Public sources of information and information needs. Journal of Community Health, 35, 676682.

Yang, H., \& Ma, J. (2020). How an epidemic outbreak impacts happiness: Factors that worsen (vs. protect) emotional well-being during the coronavirus pandemic. Psychiatry Research, 289, 113045-113050.

Yıldırım, M., Geçer, E., \& Akgül, Ö. (2021). The impacts of vulnerability, perceived risk, and fear on preventive behaviours against COVID-19. Psychology, Health and Medicine, 26(1), 1-9.

Zheng, Y., Ma, Y., Zhang, J., \& Xie, X. (2020). COVID-19 and the cardiovascular system. Natural Review: Cardiology, 17, 259260.

YÖK. (b.t.). Yükseköğretim Bilgi Yönetim Sistemi: Ö̆grenim düzeyine Göre Öğrenci Sayısı. Erişim [23.02.2021]: https://istatistik.yok.gov.tr/ 